\title{
Modernization and the Logic of Interorganizational Networks
}

\author{
Renate Mayntz
}

\begin{abstract}
In this paper an attempt is made to widen the perspective under which interorganizational networks are generally seen. It is argued that both in the economy and in policy making, network phenomena are in fact becoming more prominent. This is linked to functional differentiation, a core process of societal modernization, which implies the existence of partly autonomous societal subsystems. Their emergence is closely connected with the ascendance of formal organizations, which in turn enjoy a certain measure of autonomy. In this structural context, interorganizational network following a logic of negotiation, which extends to "constitutional" issues can provide a solution to coordination problems typical of modern societies.
\end{abstract}

\section{The Ascendance of Networks}

The world is composed of networks, not groups, says Barry Wellman (1988: 31). Our discipline, the sociology of organizations, seems to have discovered this fact roughly 20 years ago, when "interorganizational relations" became an important new topic. 'The new perspective called attention to the fact that the environment of organizations is filled with other organizations, so that for many of them, other organizations (and not amorphous publics) are the most relevant interaction partners. ${ }^{2}$ So the organization became the "focal organization," and research on interorganizational relations developed. For some time, personal interlinkages-

Renate Mayntz, Ph.D., is director of the Max Planck Institute, Köln, Germany. Her research interests include sociological macro-theory, comparative social and political research, organizational and administrative sociology, and sociology of technology. Address for correspondence is Max Planck Institute, Lothringer Strasse 78, D-5000 Köln 1 Germany.

Knowledge and Policy: The International Journal of Knowledge Transfer and Utilization, Spring 1993, Vol. 6, No. 1, pp. 3-16. 
corporate interlocks-attracted most attention (e.g., Stokman, Ziegler, and Scott, 1985); more recently, there has been growing interest in joint ventures and strategic alliances. ${ }^{3}$ The object of these studies, firms rather than other types of organizations, corresponds well with the bias in favor of productive organizations, which characterizes organization research generally. Similarly, their explicit theoretical perspective fits well with the questions generally asked in organization research: personal interlocks among firms, joint ventures, and alliances are basically considered the result of strategic organizational action to control, or adapt to, an uncertain and potentially threatening environment. Coincidentally, however, these studies highlighted a fact of macrosociological importance, i.e., that markets-at least markets dominated by firms-do not have an atomistic structure. They thus made visible an aspect of economic reality that the market models of economists had tended to ignore.

However, what is involved here may be more than a difference of perspectives; the structure of the economy may in fact have become increasingly network-like. Rogers Hollingsworth (1990), for instance, places the emergence of corporate interlocks and other forms of interfirm relations in a historical perspective. U.S. firms, he shows, first reacted to market uncertainties and antitrust legislation by the formation of large corporations, i.e., by hierarchization via horizontal and vertical integration. The capital needs of these corporations subsequently led to the emergence of corporate interlocks with investment banks who thus came to play an important role in transforming and stabilizing the American railway, steel, telephone and oil industries during the late 19th and early 20th century (Hollingsworth, 1990: 25). Later the monitoring role of the large investment banks declined, and after 1950 Hollingsworth sees the U.S. economy transformed by the emergence of various kinds of obligational networks (as he calls them), such as subcontracting and relational contracting, strategic alliances and joint ventures. In contrast to corporate interlocks, such networks are based on interactive relationships among firms-an important difference to personal interlinkage to be kept in mind when talking about interorganizational networks. Interactive relations rather than personal interlocks also characterize what for Hollingsworth is the most recent type of network emerging especially in industries that have to cope with high R\&D costs, rapid change in products, and volatile markets. He calls these promotional networks; they produce collective goods for instance through cooperation in $R \& D$, training, and information provision.

Firms in turbulent sectors of the economy have also been shown to develop collective strategies to cope with a critical economic situation (e.g., Kenis, 1991). However, this type of interorganizational network was not discovered in the framework of organizational research, but rather in policy research (a field to which Hollingsworth, too, may be said to belong). It is here, and not in organization research proper, that interorganizational networks-under the name of policy networks-had their most successful scientific career. Nor is this surprising. Organization research focuses attention on the mesolevel; its basic unit of analysis and point of reference for theoretical generalizations is the single organization (or category of or- 
ganizations). In spite of the interest in interorganizational relations, the interorganizational network therefore never became a favorite unit of analysis in the sociology of organizations. Understandably so, since networks composed of organizations pose entirely different questions from those asked in organization research: Their theoretical relevance lies on the macrolevel of society, not the mesolevel.

Organizational networks in policy formation and implementation attracted the attention of political scientists because their existence contradicted the stereotyped image of a clear state/society divide, of the state as supreme societal control center. In part this simply meant a shift away from a state-centered analytical perspective. But as in the case of market structure, what is involved here is not only a paradigm shift. For many, the notion of "policy networks" does not so much represent a new analytical perspective but rather signals a real change in the structure of the polity. Instead of emanating from a central authority, be this government or the legislature, policy today is in fact made in a process involving a plurality of both public and private organizations. A number of reasons can be adduced in support of such a thesis (see also Kenis \& Schneider, 1991: 33-36). Some of these refer to opportunities, some rather to problems. The main factor in an opportunity-driven emergence of policy networks is structural change, in particular the ascendance of formal organizations in nearly all sectors of society. An important consequence of this is the growing dispersion of power, based on the control capacity and the command over resources, which large organizations in many sectors of society enjoy. One need only think of large corporations, business and labor organizations, or medical associations to illustrate what is meant by this abstract formulation. In many policy sectors, the state therefore no longer deals with an amorphous public or with quasi groups such as social classes, but with corporate actors who are powerful in their own right.

The involvement of these corporate actors in the policy process does, of course, not follow automatically; their existence provides only an opportunity: the state can now enter into direct communication with the target groups and other parties interested in its interventions. It is therefore important that policy networks appear as problem solutions to the actors concerned; it is this that makes them a stable choice. In such a problemcentered perspective, policy networks emerge because societal actors seek participation in the policy process, while for the state cooperation with societal actors provides access to information and can increase the acceptance of policy decisions. The emergence of policy networks thus has two important implications: it is a sign of the "weak" state, but it also signals responsiveness to the heightened complexity of governing and to the growing consensus needs in modern democratic societies.

The existence of policy networks linking public and private organizations has been shown in numerous empirical studies covering the fields of health and industry, of labor, telecommunications and science policy (see, for instance, the case studies in Marin \& Mayntz, 1991). Policy networks differ with respect to their size and stability and with respect to the levelmacrosocietal or sectoral-of their articulation, and they differ between 
policy sectors, between countries, and over time. The shape of policy networks is thus anything but uniform, but the dominant impression one gains from the available empirical studies is their pervasive presence.

A tendency of network formation is also visible in the technical infrastructure of modern societies. ${ }^{4}$ The distinguishing mark of the large technical systems that have developed in the fields of transport and telecommunication, in water and in energy provision, is their network character. And again, organizations are involved: the management of vast technical networks presupposes the existence of formal organizations-railroad and electricity companies, highway construction and supervision bureaus, PTTs and air control centers. But the organizational form of the resulting sociotechnical systems is not at all hierarchical; in fact, they normally include a network of linked organizational units of smaller territorial scope (as particularly in electricity or in worldwide telecommunication) or of different functions (as particularly in road and air transport).

Obligational and promotional networks in the economy, policy networks and infrastructure networks-these parallel developments suggest that the emergence of interorganizational networks is a more general phenomenon of structural change in modern societies; indeed, it appears to be a core feature of societal modernization.

\section{Networks and Modernization}

This is not the place and time for a critical discussion of theories of modernization. For my argument it is only important to recall that a widely diffused approach defines modernity in terms of a set of societal properties, many of which are measurable by aggregating individual characteristics such as literacy, level of education, political participation, per capita income and energy consumption (Flora, 1976; Lepsius, 1990: 216-220). But modernization indicators such as these miss important structural features of the societies at which the concept is aimed.

The generally accepted hallmark of "modern" societies in structural terms is functional differentiation-not simply in the form of occupational specialization, but differentiation at the societal macrolevel through the development of functional subsystems. Though in the terminology used here this notion of modernization is connected with the name of Talcott Parsons and the school of structural functionalism, the same idea had already been expressed by Max Weber when he analyzed in detail the process of institutional differentiation between religion, politics, law, and the economy. ${ }^{5}$ Functional subsystems must-by definition, if we take the systems concept seriously - possess a boundary, an identity, in short, a certain degree of autonomy. A minimum of subsystem autonomy is already given (and this is the crucial criterion for authors like Niklas Luhmann) if distinctly different value or action orientations are permitted at the level of situations or roles, e.g., where "healing" activities may follow their own distinct logic or where the occupational role "physician" has formed. 
But a higher degree of subsystem autonomy in societies counting millions of individual members can be gained only with the existence of formal organizations able to coordinate the actions of many individuals and to represent large quasigroups-corporate actors who can act and interact, and can through such interaction achieve a measure of sectoral self-regulation (Mayntz, 1988: 22-23).

Illustrations are easily found if we think of the importance of business and labor organizations for the organized participation of the corresponding quasigroups in neocorporatist policy-making, of the role that health insurance funds and physicians' associations play in the self-government of the German health system, or of the role that research organizations such as the British Research Councils, the French CNRS or the German Max Planck Society and Forschungsgemeinschaft play in the management of the science system. The growth of formal organizations is thus not just one among many structural features of modern societies; without formal organizations, societal subsystems would not have been able to gain that degree of (relative) autonomy, which functional subsystems such as the polity, the economy, the health and the science system typically possess in highly developed western societies. $^{6}$

Subsystem autonomy, however, and hence functional differentiation at the societal level do not automatically follow from the growth of organizations; organizational growth is again only a necessary, not a sufficient condition. Only where specific functional areas are granted a minimum of autonomy, e.g., from political or religious control, will the organizations present in these subsystems enjoy in turn relative autonomy as corporate actors.

This becomes strikingly evident if we look at the East-European statesocialist societies that have recently entered a phase of revolutionary transformation. Sociological systems theory, where the concepts of functional differentiation and functional subsystem were developed, has implicitly been modelled on modern western societies and particularly the United States; we become aware of this bias as attempts to explain the recent breakdown of socialist regimes stimulates more detailed comparison between eastern and western ("capitalist") countries of a similarly high level of internal organization. One basic difference between them is the much lower degree of functional differentiation at the macro, societal level that characterized a country such as the former East German "Democratic Republic," where the dominant political party SED permeated and controlled all functional areas, including the economy, the bureaucracy, education and science. This kind of political hegemony has often been interpreted in terms of vertical, hierarchical control. But it might be more fittingly described as a kind of "vortical" integration.

The dominant party SED did not only make politically dependent existing formal organizations-industrial combines, the state bureaucracy, labor and youth organizations, satellite parties, universities and research institutions; it prevented at the same time the emergence of autonomous voluntary associations. Of course, all this was well known in the past, but it was mainly interpreted in the context of political theory, i.e., as a feature of political 
repression or totalitarianism, and not in macrosociological terms as a crucial deficit in modernization. For all the division of labor sometimes practiced even excessively, the GDR did not have autonomous functional subsystems. Today it is precisely in these terms that the erosion of the socialist regime in East Germany is being explained: not as a violent revolt against political repression, but as the consequence of blocked innovation, of lacking flexibility and responsiveness - in short, of the failure to modernize. ${ }^{7}$

In this connection it is of interest that the autonomous and responsibly acting subject plays an important role in several individual-level theories related to the notion of modernization. Thus, in the theory of civilization (Elias, 1969), the change from external behavioral controls-hierarchy, if you will, which tames uncivilized man-to the internalization of norms and hence moral self-control is a crucial feature. In the theory of socialization the very same idea can be found: the goal of successful socialization is the autonomous person, the subject able to act, which implies the abilities to make conscious choices, to exert self-control and to pursue goals other than narrowly selfish ones (Geulen, 1977). ${ }^{8}$ In legal theory, we find a corresponding idea in the concept of the "legal subject," the individual who is an autonomous agent by birth (or natural law) and can therefore enter into contractual relations defining both rights and duties. This concept of the legal subject, deeply rooted in the ideas of enlightenment, is considered the cornerstone of civil society (Mestmäcker, 1991). Far from being abstract philosophical speculations, the practical relevance of such thoughts is again underlined by analyses of the crumbling of the East European socialist regimes, where "desubjectivation" (Entsubjektivierung) ${ }^{9}$ has become a significant explanatory term. The persons growing up in a totally integrated society were subjected to tight external controls and were at the same time expected to act and feel only as members of a collectivity. They have therefore not learned to act autonomously, to assume responsibility as an act of free choice, and to rely on inner directives instead of being guided by the threat of external sanctions, all of which makes adaptation to the new situation of liberty difficult. ${ }^{10}$ The link between the deficit in structural modernization at the societal level and the deficit in individual autonomy is evident.

The capacity to act responsibly without being forced to do so is required not only of the modern individual, but also of corporate actors in modern societies. It is the precondition of collective decision making in interorganizational networks. But only in societies that are modern in a structural sense, where functional subsystems and within them, relatively autonomous corporate actors exist, can interorganizational networks with a potential for voluntary and deliberate collective action form. In a sense, this nexus between actor autonomy and network formation is implied in the network concept itself. Generally speaking, a network is a multinodal structure, any whole consisting of connected, but not tightly coupled parts. As soon as we find that parts are tightly coupled in a machine-like fashion, whether technically or by chain of command, the network concept is no longer applicable. The relative autonomy-but not the equality!-of the elements is thus a defining property of networks. ${ }^{11}$ In particular policy 
networks can only develop where there are corporate actors capable of making strategic decisions, of bargaining with other corporate actors and of striking a compromise. The existence of policy networks is therefore not only an indicator of a particular, restricted function of the state, but at the same time an indicator of societal modernization.

The view that interorganizational networks are a crucial element of societal modernization finds support in the discussion about governance forms in the economy, where the early juxtaposition of market and hierarchy (Williamson, 1975) has subsequently been extended to include other forms and particularly networks (e.g., Johanson \& Mattson, 1987; Powell, 1990). In this discussion, networks are sometimes considered to be hybrid forms (e.g., Williamson, 1985), located somewhere in the middle of a dimension that has market and hierarchy as the two opposing extremes. This is in fact so if the underlying analytical dimension is the degree of coupling: Markets are characterized by the absence of structural coupling between the elements, hierarchy by tight coupling, and networks, by definition loosely coupled, lie in between. But networks can be more than simple halfway posts between market and hierarchy: I shall argue that they can also represent a qualitatively distinct type of social structure that is characterized by a combination of elements belonging to the other two basic governance forms: on the one hand, the existence-typical of markets-of a plurality of autonomous agents (or subjects), and on the other hand the ability-typical of hierarchies - to pursue chosen goals by coordinated action.

Analytically speaking, the network thus appears as a synthesis. This suggests that networks might emerge in a dialectical process. Its abstract logic could be formulated as follows: The rise of formal organizations first destroys unstructured quasigroups (the thesis, as it were) and substitutes hierarchies for them (antithesis); but in the end the increasing formation and growing size of formal organizations destroys hierarchies and substitutes networks for them. In the field of economic activity, for instance, the rise and growth of firms transforms atomistic markets into oligopolies and monopolies. But with the continuous expansion of corporations, these become internally decentralized and are transformed into "loosely coupled systems"; $; 2$ on the external or interorganizational dimension, they become at the same time horizontally linked. A similar dialectical process can be observed in politics, where power first became concentrated and centralized in the modern state, which with continuous expansion differentiated internally and must now likewise be conceived as a complex system composed of many corporate actors who are no longer tied together to form one single, integrated hierarchy. At the same time along the interorganizational dimension, policy networks are forming.

It is, however, not only the combination of functional differentiation and organizational growth that produces the pressure to decentralize. Both hierarchy and market have dysfunctional consequences, some of which make them inherently unstable by motivating the protest of members or of relevant outside groups: ${ }^{13}$ hierarchy, because it spells subjection, the market, because it is incapable of controlling the production of negative externalities. The network, on the other hand, appears at least potentially capable to avoid 
both dysfunctions by combining the individual autonomy of the market participants with the capacity of hierarchies to pursue goals consciously and to control their actions deliberately in view of their anticipated effects. In this sense, networks may be a problem solution in a more general sense than already previously suggested with respect to the genesis of policy networks. ${ }^{14}$

The existence of formal organizations capable of strategic action ${ }^{15}$ is of course no guarantee that corporate actors will in fact cooperate to produce collective decisions. Formal organizations can act as selfishly and be as shortsighted as the individual humans who according to Hobbes only the Leviathan could tame. This raises the question of the action orientation, the "logic" typical of networks, and in particular of interorganizational networks.

\section{The Logic of Networks}

As interorganizational networks are composed of autonomous, but interdependent actors who have different, but mutually contingent interests (Marin \& Mayntz, 1991: 18), the most likely candidate for a specific network logic appears to be bargaining and exchange, in contrast to the market logic of competition and the logic of authority and obedience typical of hierarchies. Kenis and Schneider (1991: 42) for instance argue thus. And in fact, networks of exchange relations predominate in the literature of applied network analysis (see, for instance, Rogers \& Lawrence, 1981). Exchange is also a core element in models of neocorporatist decision making, where organized capital and organized labor-support public policies demanding a certain measure of self-restraint in exchange for participation in policy formation and state support of their own power position (Schmitter, 1974). Pizzorno (1977) coined the term "political exchange" for this, a concept further extended to "generalized political exchange" especially by Marin (1991a). Generalized exchange may mean that exchange is multilateral rather than bilateral, that it can be indirect (i.e., Ringtausch) rather than direct, and above all that it involves the trading of a large variety of resources, including support in particular, which have no market priceand hence call for bargaining. As exchange per se also takes place in pure market transactions, it might be this special nonmarket type of exchange that could be characteristic of interorganizational networks.

There is, of course, no doubt that in many loosely coupled actor systems, the interactions can be fittingly described as "exchanges." But exchange and bargaining do not get to the core of what happens for instance in many policy networks, in networks of sectoral self-regulation, or in R\&D networks in industry - networks that produce collective decisions, or some other kind of joint product. Of course, multilateral exchange processes have also outcomes, but as long as all participants act only to further their own individual interests, the outcome is only an unintended aggregate effect, not basically different from the aggregate effects of market processes or processes of ecological adaptation.

A similar argument could be made with respect to strategic interaction. The combination of autonomy and interdependence typical of actors in a 
network suggests that the strategic interaction logic of mixed-motive games can be applied, provided the two-person paradigm prevalent in game theory could be extended. ${ }^{16}$ But, as Windhoff-Héritier \& Czada (1991: 12) point out, the theory of (noncooperative) games attempts to explain the choice of interaction strategies only in terms of individual payoffs, which may well lead actors into a variety of social traps, such as the famous Prisoner's Dilemma.

Where interorganizational networks are able to produce collective outputs intentionally, through interaction, and in spite of diverging interests of their members, their dominant logic might most fittingly be described as negotiation. Whereas exchange and strategic interaction are guided by a calculus of individual interest and the result of the interaction is evaluated in the same "selfish" perspective, negotiations typically aim at a joint product. This joint product might be a specific technical innovation, a city plan, a strategy of collective action, or a problem solution in public policy: in any case, it is the joint product that is the "topic," the purpose of entering into negotiation, and often even the explicit reason to form the network to begin with. The interaction partners will, of course, be individually interested not only in the mere fact of producing something jointly, but also in the particulars of the agreement, which are likely to affect their individual interests, whether material or ideal. To reach an agreement at all is, however, an independent value for them, over and beyond the effects it has for the realization of their individual interests. ${ }^{17}$ In the course of the negotiations, strategic interaction can take place and exchanges can be used as a means to reach a compromise acceptable to all, but the same holds for threats and for persuasion; the logic of negotiation, therefore, cannot be reduced to any one of these modes of interaction.

It is obvious that only certain types of interorganizational networks actually do function as negotiating systems. In other interorganizational networks nothing more may take place than a stream of mutually advantageous exchanges. Negotiation may therefore not be called the network logic; but it is characteristic of networks that they are able, under conditions yet to be specified, to achieve coordination and cooperation and to do so both voluntarily and intentionally (or at least consciously), i.e., in a way neither typical of markets nor of hierarchies.

To enter into a process of negotiation presupposes the readiness to compromise, which implies taking into consideration the goals and interests of one's interaction partners. The decision to enter into negotiations at all may, as Benz has pointed out, well be motivated primarily by self-interest, but once negotiation starts, the attendant exchange of information reinforces the readiness to compromise, to find a solution to a common problem or a "just" distribution of unevenly distributed values (Benz, 1991). Benz even believes that where rules of distributive justice have not previously existed, they tend to evolve in the course of the negotiations.

Such mechanisms, of course, do not explain why negotiations should be particularly characteristic of plural actor sets, or relations among more than two, but less than maybe several hundreds or thousands of actors. If negotiation is a logic typical of networks, there must be a structural reason for this, 
because we would otherwise just be talking about different action orientations that could also be present in dyads and in large groups. Such a structural reason does indeed exist; it rests-as already suggested by the way I have formulated the issue-in the restricted number of autonomous agents of which networks are composed by definition. A very large group of actors could never reach a collective decision through direct interaction at all (though it could do so through voting). In a dyad, on the other hand, there can be negotiations, but even a small power difference between the two actors should make this a highly unstable mode of interaction, tending to transform the relationship into one of stable asymmetrical dependence. ${ }^{18}$ In plural actor sets we find in contrast both the opportunity to negotiate (because the restricted number of participants allows direct, if partly sequentialized interaction), and at the same time a low likelihood of hierarchization, since coalitions countering the superior power of any given single actor can easily form. ${ }^{19}$ Negotiation is thus a mode of interaction that is indeed particularly adapted to interorganizational networks.

Negotiation systems are stabilized if rules exist that can serve to define acceptable compromises. Compliance with certain rules is, of course, also involved in the functioning ideal market and in a hierarchical order. It is thus not rule compliance per se but rather the substantive content of the rules regulating negotiations that are their distinguishing mark. The rules that govern negotiations may refer to fair exchange, reciprocity, or a just distribution of the costs and benefits of a joint decision (or given problem solution); in any case they basically demand from each participant a voluntary restriction of his freedom of action by taking into account the possibly diverging interests of other participants and the effects his own actions may have on them - not only in order to anticipate and avoid their possible sanctions, but also because each actor is seen to have a legitimate claim that his interests are thus respected.

As a maxim, this clearly resembles Max Weber's Verantwortungsethik (ethics of responsibility), an action orientation growing out of a fully developed Zweckrationalität; ${ }^{20}$ this is the kind of rationality, which for Weber lies at the core of modernity. But such an action orientation is not only a typical product of occidental rationality, it is also highly functional for modern, strongly differentiated societies. As Willke points out, the main problem created by complex interdependencies, which typically result from functional differentiation, is not antagonism, but the indifference of actors to the negative externalities they are producing in the pursuit of their own interests (Willke, 1990). In such a situation rules are needed that oblige actors to pay attention to, and try to minimize such externalities, i.e., to act responsibly against their spontaneous inclinations. It is this that interorganizational networks functioning as negotiating systems may achieve, thus providing a possible solution to coordination problems typical of modern societies. ${ }^{21}$ But even more is involved.

Where a limited number of corporate actors operating in a given field-a policy sector, a branch of the economy, an area of technology-have tacitly agreed to abide by rules that restrict their scope for arbitrary and self-interested action, a pattern of mutually accepted organizational identities, com- 
petencies and spheres of interest may emerge. Negotiation in interorganizational networks is not only about single issues such as a specific policy decision, a joint research project etc.; it is also, and often more importantly, about the institutional arrangement itself - the constitution, as it were, of a given sector of society. After protracted domain conflicts among powerful organizations, such "constitutional negotiations" sometimes lead to a stable network configuration, ${ }^{22}$ the specific arrangement varying of course with the historical circumstances that define the terms of such negotiations. ${ }^{23}$

In several research projects at the Max-Planck-Institut für Gesellschaftsforschung that were concerned with the reconstruction of institutional developments in the German health and science systems, ${ }^{24}$ such processes have been observed. The formation of a basic institutional consensus is a strong force militating against further, politically induced change, as evidenced for instance by the surprising resistance of the West German health system to a long series of political reform attempts (Rosewitz \& Webber, 1990). Today, the preexisting institutional consensus in the West German health and science systems plays an important role in the transformation of the former East German health and science systems, which are being dismantled and reconstructed by absorption rather than giving rise to a process of institutional innovation.

This last observation may serve to underline that the institutional consolidation of interorganizational networks resulting from processes of domain negotiation is not an unmixed blessing. The network logic of negotiation is a logic of compromise. It has the advantage of permitting cooperation in spite of conflicting interests, but also the possible disadvantages of painful slowness, suboptimal results, and even stalemate. Societal modernization confronts us with a challenge. Interorganizational networks may help to cope with it, but whether they do so in fact is highly contingent.

\section{Notes}

1. Most contributions in Evan (1976), the first reader on this topic, were first published around 1970.

2. See for instance Karpik (1978), where this perspective is evident.

3. This became very evident at the 10th EGOS Colloquium, where numerous contributions in Working Group 4, "External Restructuring of Firms: Mergers, Acquisitions, Joint Ventures, Alliances," dealt with this type of interorganizational relations.

4. This is also realized by Volker Schneider (1991) who writes: "Vergleichbar der modernen Organisationsgesellschaft, in der sich mit der wachsenden Zahl korporativer Akteure ein Verflechtungszusammenhang zwischen Staat (als Makroorganisation) und den Individuen (als gesellschaftlichen Basiseinheiten) entwickelt hatte, hat sich in den letzten hundert Jahren auch in der Technik eine 'Mesoschicht' herausgebildet, in der sich technische Artefakte zu weit ausgedehnten Gebilden vernetzten."

5. It has been in particular Rainer Lepsius who has linked the well-known Weberian analyses with the notion and theory of modernization; see the essays reprinted in Lepsius (1990, especially pp. 44-62).

6. As I have argued elsewhere (Mayntz 1987), under certain conditions a highly organized functional subsystem can at the same time be more easily steered, or politically controlled; the capacity to act, a core element of autonomy, makes compliance possible as well as resistance. 
7. See Pollack (1990) and Glaeßner (1991); Glaeßner writes: “Die parteizentrierte Struktur von Gesellschaft und Politik verhinderte einen erfolgreichen Modernisierungs- und Anpassungsprozeß und führte letztlich zum Zusammenbruch des alten Systems" (Glaeßner 1991: 81-82). Quite in keeping with such an interpretation, the breakdown of the East German regime is sometimes described as implosion rather than revolution.

8. This particular variant of socialization theory, which is clearly distinct among others from the "oversocialized" conception of man, has its roots in the early writings of Talcott Parsons, but is also influenced by the symbolic interactionism of Goffman and by psychologists like Piaget and Kohlberg; see Geulen (1979).

9. The term is frequently used in discussions by social scientists from East Germany; see for instance Adler (1991).

10. The breakdown of the socialist regime in East Germany was therefore not, as many especially in the West expected, a simple act of liberalization setting free the fettered individuals and thus resulting in a big surge of creativity and initiative; instead there is evidence of widespread individual disorientation and social disintegration. Personal autonomy, which implies the abilities of self-control and of responsible action, is everywhere a highly contingent development; it does not follow automatically when hierarchy breaks down.

11. Network analysis as such does not exclude that the relations between nodes may be hierarchical because even in hierarchical organizations such as large enterprises or a public bureaucracy, the lower level units may possess that relative autonomy, which the network concept does require. Often, however, the understanding of network is narrower, implying the basic equality of the actors. Such a usage, which reflects the normative or even ideological background of much of the current attention to network phenomena, is neither useful (it would, for instance, preclude use of the network concept in the study of intergovernmental relations) nor empirically tenable, as there are clear and often very substantial power differences among the actors in many of the policy networks studied so far.

12. The use of this term in organization research, usually credited to Weick (1976), thus does not only signal a change of perspective, but at the same time a real tendency-just as in the discovery of interfirm relations and policy networks.

13. The dysfunctions of hierarchical organization such as rigidity, inflexibility, etc., have been widely discussed in the sociology of organizations and in public administration (bureaucracy! see for instance Mayntz 1978: 115-121); the dysfunctions of the market have been widely discussed under the heading of market failure. While all dysfunctions can threaten the survival of social forms in a long-term, evolutionary perspective, they need not engender protest, thus making the dysfunctional forms endogenously unstable.

14. Such a conviction seems currently to be gaining ground. See for instance the following formulation by Bernd Marin: "... to the extent that governance in a centerless society cannot be achieved by hierarchical control and without complex configurations of horizontal coordination and synchronization, interorganizational networks become the focus of attention" (Marin 1990b: 14).

15. This capability has an internal as well as external aspect; see Flam (1990), Wiesenthal (1990).

16. For a discussion of this problem and of ways to solve it see Fritz W. Scharpf (1991).

17. A similar situation is modelled in the theory of cooperative games. In negotiating systems it must not be assumed, however, that the participating actors are complete altruists or idealists and will accept any agreement that maximizes joint gain; their individual interests define a limited corridor (or window) of possible agreement.

18. Stable asymmetrical dependence is, for instance, very frequent among married couples, and is normally accepted by both partners. Asymmetrical dependence is, of course, not one-sided dependence, a relationship rather rare (and equally unstable) in dyadic face-to-face relations; see Emerson (1962).

19. With respect to coalition formation in interorganizational networks see Mayntz (1990). Of course, there are circumstances under which coalitions in plural actor sets are unlikely to form, e.g., if there is one dominant actor on whom all other actors depend. But in such a constellation network formation itself is difficult. 
20. Rather than out of an attitude of value rationality, which instead is the basis of Gesinnungsethik. There is thus no implication that a normative, or "moral" orientation is the fundament of negotiation systems.

21. Possible, of course, does not mean easy; the argument rather raises the question under which conditions interorganizational networks will be able to function in this way-a topic for another occasion.

22. Though somewhat misleadingly couched in the terminology of exchange, such a notion is also implied in Bernd Marin's concept of generalized political exchange when he writes of the "... production of surplus-value through the very regulation of the transaction process ..." and of “ ... rebalancing of given power differentials ... in order to keep a precarious network equilibrium" (Marin 1991b: 53).

23. This is strongly emphasized by Gerhard Lehmbruch who points for instance to the institutional framework, traditions of association, cultural values, and state philosophies as important factors in shaping policy networks. See for instance Lehmbruch (1991).

24. See especially Hohn and Schimank (1990) and Rosewitz and Webber (1990).

\section{References}

Adler, Frank (1991). Das "Bermuda-Dreieck" des Realsozialismus: Machtmonopolisierung-Entsubjektivierung-Nivellierung. BISS public, Wissenschaftliche Mitteilungen aus dem Berliner Institut für Sozialwissenschaftliche Studien 2, 5-46.

Benz, Arthur (1991). Umverteilung durch Verhandlungen? Kooperative Staatspraxis bei Verteilungskonflikten. Staatswissenschaften und Staatspraxis, 2, 46-75.

Coleman, James S. (1986). Social Action Systems. In James S. Coleman, Individual Interests and Collective Action. Selected Essays. Cambridge: Cambridge University Press, 85-136.

Elias, Norbert (1969). Über den Prozeß der Zivilisation. Bern: Francke.

Emerson, Richard M. (1962) Power-Dependence Relations. American Sociological Review 27, 31-41.

Evan, William M. (ed.) (1976). Interorganizational Relations. Harmondsworth: Penguin.

Flam, Helena (1990). Corporate Actors: Definition, Genesis, and Interaction. MPIfG Discussion Paper 90/11. Köln: Max-Planck-Institut für Gesellschaftsforschung.

Flora, Peter (1975). Quantitative Historical Sociology. Current Sociology, 23(2), 7-249.

Geulen, Dieter (1977). Das vergesellschaftete Subjekt. Zur Grundlegung der Sozialisationstheorie. Frankfurt:Suhrkamp.

Geulen, Dieter (1984). Sozialisationstheorie. In H. Eyferth, H.U. Otto, H. Thiersch (Eds.), Handbuch zur Sozialarbeit/Sozialpädagogik. Neuwied: Luchterhand.

Glaeßner, Gert-Joachim (1991). Der schwierige Weg zur Einheit. BISS public, Wissenschaftliche Mitteilungen aus dem Berliner Institut für Sozialwissenschaftliche Studien, 1, 65-97.

Hohn, Hans-Willy, Uwe Schimank (1990). Konflikte und Gleichgewichte im Forschungssystem: Akteurkonstellationen und Entwicklungspfade in der Staatlich finanzierten außeruniversitären Forschung. Frankfurt a.M.: Campus.

Hollingsworth, Rogers J. (1990). The Governance of American Manufacturing Sectors: The Logic of Coordination and Control. MPIFG Discussion Paper 90/4. Köln:Max-Planck-Institut für Gesellschaftsforschung.

Johanson, Jon, L.G. Mattson (1987). Inter-organizational Relations in Industrial Systems: A Network Approach Compared with the Transaction-Cost Approach. International Studies of Management and Organisation, 18, 34-48.

Karpik, Lucien (ed.) (1978). Organization and Environment. London: Sage.

Kenis, Patrick (1991). The Preconditions for Policy Networks: Some Findings from a Three-Country Study on Industrial Restructuring. In B. Marin, R. Mayntz (Eds.), Policy Networks: Empirical Evidence and Theoretical Considerations. Frankfurt a.M.: Campus, 297-330.

Kenis, Patrick, Volker Schneider (1991). Policy Networks and Policy Analysis: Scrutinizing a New Analytical Toolbox. In B. Marin, R. Mayntz (Eds.), Policy Networks: Empirical Evidence and Theoretical Considerations. Frankfurt a.M.: Campus, 25-54.

Lehmbruch, Gerhard (1991). The Organization of Society, Administrative Strategies, and Policy Networks. In R.M. Czada, A. Windhoff-Héritier (Eds.), Political Choice-Institutions, Rules, and the Limits of Rationality. Frankfurt: Campus, 121-158.

Lepsius, M. Rainer (1990). Interessen, Ideen und Institutionen. Opladen: Westdeutscher Verlag.

Marin, Bernd (Ed.) (1990a). Generalized Political Exchange. Antagonistic Cooperation and Integrated Policy Circuits. Frankfurt a.M.: Campus. 
Marin, Bernd (1990b). Generalized Political Exchange. Preliminary Considerations. In B. Marin (Ed.), Generalized Political Exchange. Antagonistic Cooperation and Integrated Policy Circuits. Frankfurt: Campus, 37-65.

Marin, Bernd, Renate Mayntz (Eds.) (1991). Policy Networks: Empirical Evidence and Theoretical Considerations. Frankfurt a.M.: Campus.

Mayntz, Renate (1978). Soziologie der öffentlichen Verwaltung. Heidelberg: C.F. Müller.

Mayntz, Renate (1987). Politische Steuerung und gesellschaftliche Steuerungsprobleme-Anmerkungen zu einem theoretischen Paradigma. In Th. Ellwein et al. (Eds.), Jahrbuch zur Staats- und Verwaltungswissenschaft. Vol. 1/1987. Baden-Baden: Nomos, 89-110.

Mayntz, Renate (1988). Funktionelle Teilsysteme in der Theorie sozialer Differenzierung. In R. Mayntz, B. Rosewitz, U. Schimank, R. Stichweh, Differenzierung und Verselbständigung. Zur Entwicklung gesellschaftlicher Teilsysteme. Frankfurt a.M.: Campus, $11-44$.

Mayntz, Renate (1990). Politische Steuerbarkeit und Reformblockaden: Überlegungen am Beispiel des Gesundheitswesens. Staatswissenschaften und Staatspraxis, 1, 283-307.

Mestmäcker, Emst-Joachim (1991). Die Wiederkehr der bürgerlichen Gesellschaft und ihres Rechts. Rechtshistorisches Journal (in print).

Pizzorno, Alessandro (1977). Scambio politico e identità colletiva nel conflitto di classe. Rivista Italiana di Scienza Politica, 7, 165-198.

Pollack, Detlef (1990). Das Ende einer Organisationsgesellschaft. Systemtheoretische Überlegungen zum gesellschaftlichen Umbruch in der DDR. Zeitschrift für Soziologie, 19, 292-307.

Powell, Walter W. (1990). Neither Market nor Hierarchy: Network Forms of Organization. Research in Organizational Behavior, 12, 295-336.

Rogers, Everett M., D. Lawrence Kincaid (1981). Communication Networks. Toward a New Paradigm for Research. New York: Free Press.

Rosewitz, Bernd, Douglas Webber (1990). Reformversuche und Reformblockaden im deutschen Gesundheitswesen. Frankfurt a.M.: Campus.

Scharpf, Fritz W. (1991). Games Real Actors Could Play: The Challenge of Complexity. Journal of Theoretical Politics, 3, 277-304.

Schmitter, Phillip C. (1974). Still the Century of Corporatism? Review of Politics, 36, 85-131.

Schneider, Volker (1991). Kooperative Akteure und vernetzte Artefakte. W. Rammert, G. Bechmann (Eds.), Jahrbuch Technik und Gesellschaft 6: Großtechnische Systeme und gesellschaftliche Entwicklung. Frankfurt a.M.: Campus (in print).

Stokman, Frans N., Rolf Ziegler, John Scott (Eds.) (1985). Networks of Corporate Power-A Comparative Analysis of Ten Countries. Cambridge: Polity Press.

Weick, Karl E. (1976). Educational Organizations as Loosely Coupled Systems. ASQ, 21, 1-19.

Wellman, Barry (1988). Structural Analysis: From Method and Metaphor to Theory and Substance. In B. Wellman, S.D. Berkowitz (Eds.), Social Structures: A Network Approach. Cambridge: Cambridge University Press, 19-61.

Wiesenthal, Helmut (1990). Unsicherheit und Multiple-Self Identität: Eine Spekulation über die Voraussetzungen strategischen Handelns. MPIfG Discussion Paper 90/2. Köln: Max-Planck-Institut für Gesellschaftsforschung.

Williamson, Oliver E. (1975). Markets and Hierarchies: Analysis and Antitrust Implications. A Study of the Economics of Internal Organization. New York: Free Press.

Williamson, Oliver E. (1985). The Economic Institutions of Capitalism. New York: Free Press.

Willke, Helmut (1990). Political Intervention-Operational Preconditions for Generalized Political Exchange. In B. Marin (Ed.), Gooernance and Generalized Exchange. Self-Organizing Policy Networks in Action. Frankfurt a.M.: Campus, 235-254.

Windhoff-Héritier, Adrienne, Roland Czada (1991). Introduction. In R. Czada, A. Windhoff-Héritier (Eds.) Political Choice. Institutions, Rules, and the Limits of Rationality. Frankfurt a.M.: Campus, 9-23. 